\title{
Using Video-Based Instruction To Integrate Ethics Into The Curriculum
}

Ali M. Sedaghat, Loyola University Maryland, USA

Steven M. Mintz, California Polytechnic State University, USA

George M. Wright, Loyola University Maryland, USA

\begin{abstract}
This paper describes a video case discussion project based on the IMA's Statement of Ethical Professional Practice that was administered in a cost accounting class to assess the extent to which students were able to identify and discuss ethical issues raised by the facts of a case scenario. The case was developed by the IMA to advance the continuing education in ethics of financial executives and management accountants. The scenario realistically portrays the kind of pressures faced by management accountants to go along with top management decisions that are driven by self-interest rather than proper accounting. We use a highly structured approach for direct assessment of student learning with pre-established rubrics. Indirect assessment of learning is approximated by a survey of students' subjective reactions. In general, we conclude IMA's video Success without Compromise provides an opportunity for students to apply ethics standards in a realistic setting and encourages students to become active participants in the learning experience.
\end{abstract}

Keywords: IMA; Code Of Ethics; Accounting Education; Video Instruction

\section{INTRODUCTION}

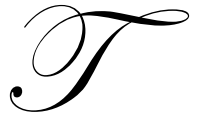

he purpose of this paper is to describe the results of a video project to develop student ability to identify and evaluate ethical issues, identify and evaluate alternative courses of action, and resolve ethical dilemmas. We use the Institute of Management Accountants' (IMA) Ethics Series video titled: Success without Compromise that is shown in conjunction with the IMA Statement of Ethical Professional Practice (IMA code) and developed for professional continuing education purposes for financial executives and management accountants. Even though this video is designed for professional accountants, it is equally applicable to students learning to become accounting professionals in all fields because it includes the broad values of a professional: competence, confidentiality, integrity and credibility. We show the IMA video to accounting students and develop assignments to enhance the learning experience and support students' ability to analyze ethical dilemmas in the workplace. We also assess the results of the video project and make recommendations to strengthen and expand future use of the IMA video.

The Principles that underlie the IMA code including honesty, fairness, objectivity, and responsibility, pertain to all professionals and closely relate to the Principles of Professional Conduct of the American Institute of CPAs. Therefore, we believe the use of the IMA code to analyze ethical issues faced by management accountants is a valid way to teach ethics to accounting students. Indeed, Haywood et al. (2004) use games to enhance student understanding of professional and ethical responsibilities in accounting and apply the standards of IMA code in a managerial accounting course. The authors point out in their study that these aspects of professional and ethical responsibilities provide a useful framework to consider how reported accounting scandals, such as the Enron fraud, violate those standards. 
Our specific objectives in this paper are:

1. To explain the framework used to enhance student abilities to analyze ethical issues they might encounter as accounting professionals

2. To present our assessment, both direct and indirect, of the effectiveness of this approach to student learning

3. To report the results of this pilot study and observations as well as recommendations for future use

\section{IMA ETHICS CASE STUDY}

In this project we used the IMA video presentation Success without Compromise (Institute of Management Accountants, 2010). The video was originally created to provide continuing professional education for members of the IMA and has been expanded to enable universities to use the video in classroom instruction. The video is available to faculty at a discounted price of $\$ 100$ with the permission to use it in the classroom. Our recommendation is to have the library acquire it or seek permission to use department funds since it can benefit accounting faculty over a number of years.

This video describes a real-world situation at a fictional company, InfoCom. Ethical issues at InfoCom arise when the InfoCom CEO begins to question why a pending merger with another company has reached a snag. Specifically, questions arise whether software development costs should be capitalized instead of being expensed as required by generally accepted accounting principles - at least up to the point of technological feasibility.

The CFO confronts the controller when he realizes that the merger will not occur as they had planned unless earnings improve. The CFO suggests that "ambiguity" in accounting rules could be exploited to capitalize the costs ("doubts" about whether the company has passed the point of establishing technological feasibility) in order to enhance earnings prior to the merger and potentially increase the expected bonuses.

Using the IMA Code that is presented in Exhibit 1 as the basis for instruction, we developed questions to assess whether students have incorporated the values of the Code into their decision making as would be expected of an accounting professional. In particular, we looked at the following Principles - honesty, objectivity and responsibility - and the Standards: - integrity and credibility. These are core ethical values for all accounting professionals and are particularly relevant to the IMA video scenario. Our analysis indicates that the actions of the $\mathrm{CFO}$, who pushes for premature capitalization, do not meet the ethical requirements of the IMA Code. He is willing to ignore the credibility aspect of information that it should be communicated objectively and fairly and in a way that enables the potential merger partner to understand the true status of capitalization costs. The CFO's biased interpretation of the software capitalization rules shows a lack of integrity because there is no intention to fully disclose the facts and circumstances surrounding if and when costs should be capitalized. Finally, the overarching principles in the IMA Code of honesty, objectivity and responsibility are violated by the CFO by placing the perceived best interests of InfoCom and his own self-interest ahead of those of the merger partner. The merger partner, in this case, is the user of the financial information and has an ethical right to expect that the information provided will be accurate and reliable before deciding whether to finalize the merger arrangement.

\section{LITERATURE REVIEW}

Ethics in the accounting profession has a long history (Loeb, 1978). Integration of ethics across courses in accounting does not. Levy and Mitschow (2008) identify Armstrong (1993) as developing the first "substantive, well-considered proposal for improving accounting ethics education." However, Loeb (1988) is generally credited as one of the first to call for increased ethics education by identifying seven specific goals for the endeavor. He was followed by Langenderfer and Rockness (1989) who discussed the problems and issues in integrating ethics into the accounting curriculum. Mintz (1990) was one of the first to examine ethics in the management accounting curriculum and identify where ethics issues might be covered. He conducted a survey of 333 members of the management accounting section of the American Accounting Association to determine the extent of ethics integration. The results indicated 70 percent of the respondents taught a beginning course in management or a cost accounting course and 52.6 percent integrated ethics into their courses. He recommended teaching ethics in all areas of the accounting curriculum by combining lectures with input from practitioners through interactive classroom 
discussions and using role-playing case studies. Mintz (1995) also analyzed the ethical obligations of management accountants in the context of the IMA Standards of Ethical Conduct for Management Accountants, the predecessor to today's IMA standards. He concluded that coverage of the IMA standards was an important way to sensitize students to management accountants' obligations. Davis (1998) evaluated different alternative approaches for integrating professional ethics into a curriculum, including extracurricular activities, guest lecturers, and taking a course outside the discipline. He suggests that the most effective approach to teaching professional ethics is to incorporate ethics education into courses within that discipline. This allows the instructor to relate the specific discipline issues with professional ethics in the field. Some instructors may not feel comfortable and competent to address ethics within their discipline. This suggests that a professionally developed video and case study, accompanied by guest speakers familiar with the case, might increase the instructor's comfort level in teaching ethics and enhance the student learning experience.

In more recent years, Hanson (2010) suggests that integration of ethics into business education can be accomplished by enlisting the participation and engagement of businesses and business professionals who can use their experiences to demonstrate the integral role of ethics in a real world business setting. Freeman (2009) believes that business and ethics are intertwined and that ethics education should be integrated with all business disciplines. Business is done by people, and trust is the most important element of trade and business. Ethical values influence behavior, and ethical behavior will create a trusting environment necessary for a successful business operation. The question, therefore, is not if we should incorporate ethics in our business or accounting areas, but how we do it. Freeman suggests that the best approach for faculty is to make sure that they are not claiming to know all ethical standards and to be ethical paragons. Instead, they should permit students to reflect on their own moral and ethical values and encourage them to participate in conversations about ethics.

Video as a component of classroom instruction has long been studied, most frequently in foreign language classes (Canning-Wilson, 2000; Zhao, 2003; Castleberry, \& Evers, 2010). Fink (2003) suggests that an environment rich in diverse learning experiences improves students' abilities to absorb and retain material presented. Delaney and Coe found that ethics instruction in upper-level accounting courses is effective in increasing moral reasoning ability (Delaney, \& Coe, 2008). This suggests that video may be an effective component in teaching ethics in a cost accounting class.

There are two very relevant studies of video instruction in an accounting course to date. The first is by Awasthi and Staehelin (1995). The authors used the IMA Standards of Ethical Conduct for Management Accountants as a tool for students to analyze ethical issues after showing a video titled "The Order: A Progressive Disclosure Vignette." The video was produced by Arthur Andersen as part of its faculty ethics training programs in the 1990s. Students were expected to assess whether the IMA's standards were violated by a management accountant who went along with the purposeful acceleration of production and shipping of product before the date of the contract agreement with a customer to increase revenue and improve bonuses. The primary ethical issues discussed were the failure of the accountant to act objectively and with integrity because he permitted the production manager to undertake an action that potentially violated an agreement and did not act to correct the matter when problems in the production process arose.

Savage et al. (2008) showed the British movie the Rogue Trader that depicts internal control problems Barings Bank that led to a massive fraud in 1995. The result was the collapse of the London bank because of unauthorized trading in futures contracts in the Singapore office of the bank by rogue employee, Nick Leeson. The internal controls were weak at the bank and management oversight virtually nonexistent. The video was shown in an accounting information systems course where discussions about internal control are important. Students viewed the movie and then used the internal control framework developed by the Committee of Sponsoring Organizations (COSO, 1992) to critically analyze the collapse of Barings. They were required to write a report that identifies the internal control problems at Barings and make a team presentation to accounting professionals who might attend a meeting to discuss the issues raised in the report. The authors concluded based on their study that the video project and follow-up assignments enhanced student learning about COSO and internal controls. 


\section{ASSESSING STUDENT LEARNING}

The Association to Advance Collegiate Schools of Business (AACSB), founded in 1916, is an association of more than 1,200 educational institutions, businesses and other organizations in 78 countries and territories. Its mission is to advance quality management education worldwide through its accreditation process. That process includes specific standards for the assessment of learning. AACSB (2007) outlines five steps in the assessment process including: (1) establishing learning goals and objectives; (2) alignment of curricula with adopted goals; (3) identification of assessment instruments and measures; (4) collection, analyzing, and dissemination of assessment information; and (5) using assessment information for continuous improvement including documentation that the process is being carried out on an ongoing, systematic basis. We focus the discussion on developing instruments to assess learning and collecting and analyzing data.

The AACSB standards show a strong preference for direct over indirect assessment of student learning. Direct assessment incorporates course-embedded assessment including testing, capstone projects such as case analysis and discussion and term papers. We believe a video project also meets the criteria for capstone evaluation. Direct assessment can also include standardized examinations and pre-test/post-test as might be used to assess ethics learning through principled reasoning instruments such as the Defining Issues Test.

Indirect assessment often relies on retrospective devices such as students exit interviews, surveys of student learning, and student evaluations of classroom instruction. Shaftel and Shaftel (2007) point out that "the direct, lowinference nature of tests can be contrasted with indirect forms of measurement that do not rely on actual performance by the individual being evaluated.

\section{CURRICULA APPROACH TO USING THE IMA VIDEO}

The IMA video, Success without Compromise, is divided into two parts. The first describes the IMA's Statement of Ethical Professional Standards (see Exhibit 1) in detail and how it should influence meeting one's professional obligations as a financial executive or management accountant. The second part presents the InfoCom case study that depicts the discussions between the CFO of the company, Evan Slater, who is pushing for early capitalization of software development costs, and other employees who are questioning whether such treatment is allowed by the accounting rules. The CEO, Gordon Jamison, plays an important role because he can't understand why a snag has developed in the merger discussions. The most critical role may be played by the controller, Karen Patella, who is being pressured by Slater to accept his proposed accounting so that the merger is more likely to go through, top management bonuses will increase, and he will be able to retire sooner rather than later. Patella is the accountant faced with the ethical dilemma in this case - whether to go along with the proposed accounting that at best is questionable.

To design the video project we considered the following matters: the nature of the discussion about the video scenario; the focus of the conversation on specific or general issues including uncertainties about capitalization of costs; the stakeholders affected by the events depicted in the video; and how best to make the learning experience useful for students with respect to their future development as accounting professionals. We encouraged students to think critically in analyzing the ethical issues presented in the video always using the IMA code as the foundation for their analysis.

To provide students with the necessary background for the video project, we use assigned readings, class discussions, written assignments, and guest speakers. Specific directions are provided to the students prior to commencing the project to guide them through the process including the learning objectives and outcomes expected of their work. These appear in Appendix 1. These guidelines help students to organize and direct the learning process.

The video depicts ethical issues within real-life business operations and pressures imposed on management accountants to go along with decisions made by higher-ups that can be tainted by self-interest. The goal is to encourage students to think deeply about their own ethical values, consider the consequences of their actions, and make decisions after thoughtful discussion. They are required to articulate their preferred resolution to the ethical 
dilemma presented in the video in either a written assignment or in their own, student-produced video as explained in Appendix I.

At our institution the undergraduate core curriculum includes a course in ethics and students are challenged to understand the ethical dimensions of their personal and professional lives throughout the curriculum. The accounting courses incorporate ethics issues and directly involve students in thinking about and resolving ethical dilemmas faced by accounting professionals in the performance of a variety of professional services. The cost accounting course was used for the project since students at that level have completed an introductory managerial course and possesses a level of sophisticated knowledge needed to deal with ethical issues faced by management accountants.

Our goal for the project was published on the course Blackboard site and communicated to students both verbally and by hard copy. The goal comes directly from the departmental mission: to insure students are able to identify ethical issues and apply ethical principles to make ethical business decisions. Our pedagogical approach was to provide flexibility to students in reporting what they have learned via either a written, individual paper or a groupproduced video, in which they play the parts of various InfoCom employees in a "sequel." Appendix 2 describes the responsibilities of students in the role-play situation. We believe that the diversity of options enhances the potential learning experience of all students in the class as they benefit from the approach taken by other teams and subsequent classroom discussions.

The ethical analysis in each alternative approach relies on the ability of a student to identify the ethical issues in the case and develop strategies to deal with those issues by drawing on the standards in the IMA code. Alternative courses of action are identified and consequences considered before deciding on an appropriate course of action. The main difference between the alternatives is the group video assignment (Alternative II) personalizes the process for students and may be a more enriching experience.

\section{DIRECT ASSESSMENT OF LEARNING}

Direct assessment measures student outcomes through evaluating deliverables. Our approach to direct assessment used the existing methodologies in place to prepare us for AACSB re-accreditation. For the past eight years, we have had in place a school-wide process for assessing learning outcomes of each discipline. We identified courses directly associated with established learning goals. For each of these courses, we developed a structured "rubric," a protocol for assigning a numerical value for components of learning goals associated with the course. The advantage of using a rubric is that it explains to students the criteria against which their work will be judged. Appendix 3 presents the rubric we used for direct assessment.

To assess how well students were able to apply IMA standards in real-world situations, we evaluated the students' written responses to four questions about the IMA video (see Alternative I in Appendix 1 for complete instructions for this writing assignment).

1. What are the ethical issues apparent here?

2. How would you deal with these ethical issues?

3. What are the consequences of your proposed courses of action?

4. What basis do you have for your proposed courses of action?

A total of 61 responses were evaluated by the team of one additional faculty member and two accounting practitioners who serve on the department advisory council. The faculty member evaluated all 61 responses; the practitioners each evaluated half of the responses. Evaluators used the scoring rubric in Appendix 3 to score the students' responses. The scoring rubric required each evaluator to assess each student's response in terms answering the foregoing four questions. The rubric called for the evaluator to award one, two, or three points for each question, according to these guidelines. 


\section{Recognizes Ethical Issues}

1. Unable to recognize ethical issues.

2. Recognizes and identifies at least one ethical issue correctly.

3. Recognizes multiple ethical issues.

\section{Proposes Solutions to Ethical Dilemmas}

1. Unable to propose any plausible solutions to the dilemma.

2. Proposes one or two solutions to the dilemma that are plausible in terms of the principles and standards of IMA's Statement of Ethical Professional Practice.

3. Proposes three or more solutions to the dilemma that are plausible in terms of the principles and standards of IMA's Statement of Ethical Professional Practice.

\section{Recognizes Consequences of Solutions}

1. Unable to articulate either positive or negative consequences to most of the proposed solutions; fails to consider a wide range of stakeholders.

2. Articulates either positive or negative consequences; considers only a limited number of stakeholders.

3. Articulates both positive and negative consequences for a wide range of stakeholders.

\section{Justifies Solutions Using Ethical Reasoning}

1. Fails to correctly identify ethical theory or principle or uses it incorrectly to justify recommendation.

2. Identifies theory or principle and attempts to use it to justify recommendation.

3. Clearly identifies ethical theory or principle and uses it to justify recommendation.

For each evaluation, scores for each question were averaged across the three scorers and then rounded to the nearest integer. Then scores for all four questions were summed, giving the final score for each student paper. By construction, the score could range from 4 to 12 . The average score was 9.9 and the standard deviation was 1.64. Distribution of these overall evaluations of the 61 student papers appears in Figure 1.

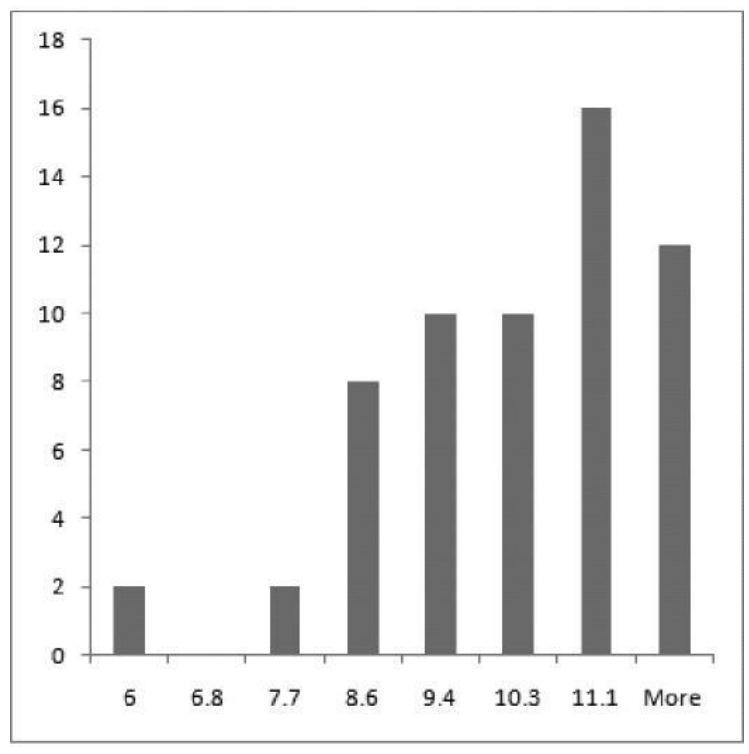

Figure 1: Distribution of Evaluations 
Table 1: Interpretation of Learning Scores

\begin{tabular}{cl}
\hline Scoring & \multicolumn{1}{c}{ Assessment } \\
$4-6$ & Does not meet expectations \\
$7-9$ & Meets expectations \\
$10-12$ & Exceeds expectations \\
\hline
\end{tabular}

In order to decide where student scores stand with respect to expectations, we find a confidence interval for the population mean score $\mu$, where the population standard deviation $\sigma$ is unknown and the sample size is more than 30. For a $95 \%$ confidence interval we have

$$
\bar{x}-z_{\alpha / 2} \frac{\sigma}{\sqrt{n}}<\mu<\bar{x}+z_{\alpha / 2} \frac{\sigma}{\sqrt{n}}
$$

where $\bar{x}$ is the mean of a sample of size $n$ from a population with known variance $\sigma^{2}$ and $z_{\alpha / 2}$ is the value of the standard normal distribution leaving an area of 0.025 to the right. The point estimate of $\mu$ is $\bar{x}=9.9$. Since the sample size 61 is large, the standard deviation $\sigma$ can be approximated by $s=1.64$. Hence the $95 \%$ confidence interval is

$$
9.9-1.96 \frac{1.64}{\sqrt{61}}<\mu<9.9+1.96 \frac{1.64}{\sqrt{61}}
$$

which reduces to

$9.49<\mu<10.31$.

Our guidelines (Appendix 3) assess learning scores as shown in Table 1. Scores in the range 7-9 indicate expectations are met; scores in the range 10-12 indicate expectations are exceeded. Given the confidence interval we just computed, we conclude that student learning meets or exceeds expectations.

Table 2 shows statistics on overall scores by gender. We were curious as to whether there is a difference between scores by males and females in the class. We tested the null hypothesis that the average male score differs significantly from the average female score using a t test. We cannot reject that hypothesis $(\mathrm{t}=0.15158, \mathrm{p}=$ 0.88002 ) and find no reason to conclude there's a difference by gender.

Table 2: Scoring Statistics by Gender

$\begin{array}{lc}\text { Females } & \text { Males } \\ \mu=10.2 & \mu=9.8 \\ \sigma=1.25 & \sigma=1.78\end{array}$

Table 3 shows statistics on overall scores by class. We cannot reject the null hypothesis that the average junior score differs significantly from the average senior score $(\mathrm{t}=0.18558, \mathrm{p}=0.85340)$ and find no reason to conclude there's a difference by class year.

Table 3: Scoring Statistics by Class

$\begin{array}{cc}\text { Juniors } & \text { Seniors } \\ \mu=9.9 & \mu=10.0 \\ \sigma=1.59 & \sigma=2.00\end{array}$

\section{INDIRECT ASSESSMENT OF LEARNING}

Indirect assessment of student learning was accomplished via self-reported student opinion. We solicited student evaluations of the IMA Video project by using the instrument presented in Appendix 4. Students were asked 
to state, with respect to the video-based ethics component, the strengths of the project, weaknesses, and any overall comments that might help to enhance the experience for future students.

To interpret and summarize the students' reactions, we categorized the "overall reaction" comments as negative, neutral/absent, or positive. The tabulation of that categorization appears in Figure 2. Of the 66 responses, there were zero negative overall comments, fourteen neutral/absent comments, and 52 positive comments. All comments appear in Appendix 5.

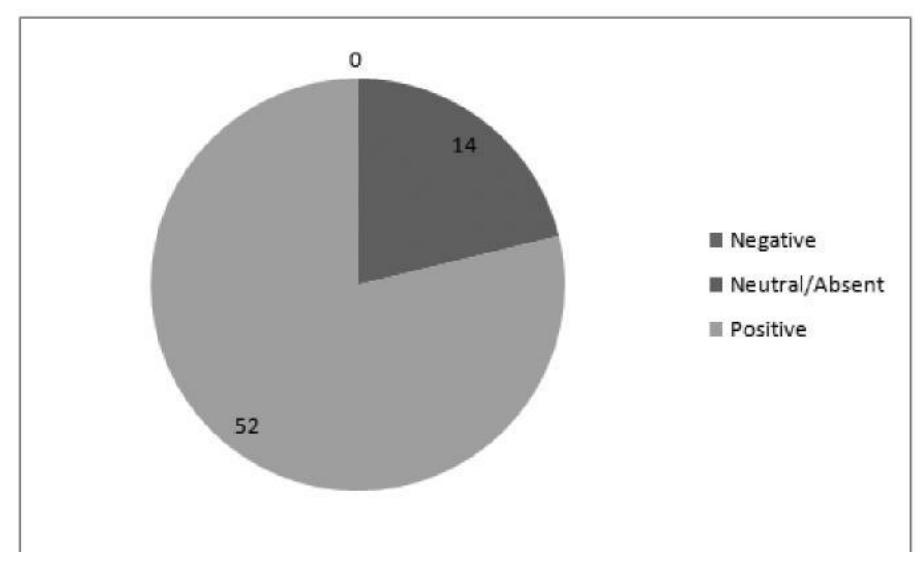

Figure 2: Tabulation of Overall Reaction

Most of the students gave high ranking to guest speakers and considered them insightful, reinforcing the points made in the video, by providing real life examples. Students enjoyed watching the video and appreciated a departure from a typical lecture format. They found it useful that the video was posted on the Blackboard. Most students expressed satisfaction with having choices in making a group video response or writing a term paper. Several students suggested that we should require everyone to participate in making a video response to the issue. Students expected more specific instructions for writing the paper or preparing the video in advance rather than at the second session. Some students suggested shortening the program to one or two sessions, permitting them to watch the video on their own. Overall comments were mostly positive and indicated a high degree of satisfaction with the project.

\section{LIMITATIONS}

One limitation of our study is due to the fact that we asked each accounting practitioner to evaluate only half the responses. Intended to lighten the load on our professional volunteers, this caused a problem because, even though they both used the same scoring rubric, they produced significantly different results. Table 4 shows the differences.

Table 4: Scoring Statistics by Scorer

$\begin{array}{ccc}\text { Faculty } & \text { Practitioner } A & \text { Practitioner } B \\ \mu=9.6 & \mu=9.41 & \mu=7.5 \\ \mathrm{a}=1.79 & \mathrm{a}=1.20 & \mathrm{a}=2.00\end{array}$

The faculty scorer and Practitioner A scored the papers the same on average $(\mathrm{t}=0.39, \mathrm{p}=0.70)$. Let $\mu_{1}$ be the average score for the faculty scorer and Practitioner A combined (9.57, standard deviation 1.52). Let $\mu_{2}$ be the average score for Practitioner B (7.5, standard deviation 2.00). We face a small sample test of hypothesis about the difference between the means of two normal populations having unequal and unknown variances and different sample sizes. We will test the null hypothesis 
$H_{0}: \mu_{1}=\mu_{2}$ or $\mu_{1}-\mu_{2}=0$

versus the alternative hypothesis

$H_{1}: \mu_{1}>\mu_{2}$ or $\mu_{1}-\mu_{2}>0$.

We will use the $T^{\prime}$ 'statistic, where $T^{\prime}$ is a random variable having approximately the $t$ distribution with

$$
v=\frac{\left(s_{1}^{2} / n_{1}+s_{2}^{2} / n_{2}\right)^{2}}{\left[\left(s_{1}^{2} / n_{1}\right)^{2} /\left(n_{1}-1\right)\right]+\left[\left(s_{2}^{2} / n_{2}\right)^{2} /\left(n_{2}-1\right)\right]}
$$

degrees of freedom. Substituting, we have

$$
v=\frac{\left(1.52^{2} / 56+2.00^{2} / 30\right)^{2}}{\left[\left(1.52^{2} / 56\right)^{2} /(56-1)\right]+\left[\left(2.00^{2} / 30\right)^{2} /(30-1)\right]}
$$

which reduces to $32.68 \cong 33$ degrees of freedom. The 0.05 confidence level critical region is thus $T^{\prime}>1.69$. The test statistic is

$$
t^{\prime}=\frac{\bar{x}_{1}-\overline{x_{2}}}{\sqrt{\left(s_{1}^{2} / n_{1}\right)+\left(s_{2}^{2} / n_{2}\right)}}
$$

Substituting, we have

$$
t^{\prime}=\frac{9.57-7.5}{\sqrt{\left(1.52^{2} / 56\right)+\left(2.00^{2} / 30\right)}},
$$

which reduces to 4.96, well inside the critical region. We conclude that Practitioner B graded significantly lower than the faculty scorer and Practitioner A combined.

In addition to repeating the study without the partial scoring procedure, we have identified an additional enhancement for the follow-up to our pilot study that will be conducted by one of the authors. We scored the four areas of problem recognition, solution generation, consequences identification, and justification of solutions separately. In sharing subjective opinions of the students' performance, the three graders agreed that the weakest area was justification of solutions suggested on the basis of ethical theory. There is not an objective, statistical basis for this opinion. The average score for justification was not significantly different from the average scores for the three other areas $(\mathrm{t}=0.82033, \mathrm{p}=0.41528)$.

One reason the graders thought the justification was weaker than the other areas was because students tended to justify their recommended solutions only on the basis of conformance to IMA standards. The graders had initially expected students to integrate material from their business ethics course and appeal to ethical theories such utilitarianism, deontology, or the categorical imperative. But, in the course of grading the student responses, each grader had independently decided that, in the absence of explicit instructions to consider ethical theories beyond the IMA guidelines, it was natural for them to use those guidelines as the primary basis for their necessarily brief responses. In the follow-up study, we will add a fifth area for scoring. We will distinguish between justification on the basis of the IMA code and justification on the basis of ethical theories from the students' core business ethics course. The latter will be reviewed with students to insure they understand just how to apply specific ethical reasoning methods to the video scenario.

In terms of alternative approaches, we have a distinct option available. Three student teams chose to produce their own videos (Alternative II in Appendix 1). The production values of some of the videos were better than we expected. The students said they enjoyed the assignment and comments received suggested using only 
Alternative II. In the follow-up study an attempt will be made to evaluate student learning via the video approach. It would be interesting to see whether one approach - a written analysis $v s$. a video analysis - produces a difference in terms of assessment of learning.

\section{SUMMARY AND CONCLUSIONS}

We used the IMA video Success without Compromise to expose students in a cost accounting course to professional ethics standards for management accountants. This was a pilot study and we did not anticipate some of the issues that arose in the scoring, including the inability of students to apply ethical reasoning to evaluate the ethical dilemma presented in the video. In retrospect, we believe the ethical analysis can be richer by separating out the evaluation of students' ability to apply the IMA standards and their ability to demonstrate ethical analysis through philosophical reasoning methods. We feel that given the limitations of the pilot study, the results do demonstrate that exposure to the IMA standards sensitized students to the ethical issues raised in the video.

The study describes the tools used to assess student learning through a highly structured approach for direct assessment with pre-established rubrics. Indirect assessment of learning is approximated by a survey of students' subjective reactions. Based on the results, we believe the video project helps students exceed expectations with respect to recognizing ethical issues, proposing solutions, articulating positive and negative consequences of the proposed solutions for stakeholders, and using the IMA's ethics standards to justify recommended solutions.

Our study also shows there is no significant difference in learning between genders or between juniors and seniors. It could be that these results might have been different, especially between juniors and seniors, if we had required students to use ethical reasoning. The students complete the business ethics course either in their junior or senior year so that it is quite possible some did not complete it prior to taking the cost accounting course. That is a much less likely outcome if they were in their senior year. The follow-up study will provide clearer results in this regard.

Finally, we are quite heartened by the fact that most of the students believe the video exercise was a positive learning experience. It was our goal at the outset to try something different in teaching ethics to accounting students rather than rely primarily on a professional code of ethics, in this case the IMA standards. The use of the video encouraged students to get involved with the class discussion and gave them an opportunity to express their ideas about a common ethical dilemma encountered by management accountants in the workplace.

\section{AUTHOR INFORMATION}

Dr. Ali Sedaghat is an associate professor of accounting at Loyola University in Maryland. He is a member of the American Accounting Association, Institute of Management Accounting, and the Decision Science Institute. He has published in Issues in Accounting Education, Advances in Accounting, Accounting Educators Journal, Journal of Corporate Taxation, The Business \& Taxes Quarterly, Management Accounting and Journal of International Accounting. He has presented papers at more than twenty national and international professional meetings and has been granted Coopers and Lybrand Silver medallion for his publication in the Management Accounting Magazine. E-mail: asedaghat@loyola.edu

Dr. Steven Mintz is a professor of accounting ethics in the Orfalea College of Business at the California Polytechnic State University in San Luis Obispo. Dr. Mintz enjoys an international reputation as a leader in academic ethics. His textbook titled Ethical Obligations and Decision Making in Accounting: Text and Cases ( $2^{\text {nd }}$ edition) was published by McGraw-Hill Irwin in 2011. He teaches an accounting ethics course at Cal Poly. Dr. Mintz has published more than 20 research papers in accounting business ethics. He also has developed continuing education courses in CPA ethics for 20 states. E-mail: smintz@ calpoly.edu

George Wright is an emeritus Associate Professor of Information Systems at Loyola University Maryland. After service as a Navy fighter pilot (F8 Crusader), he worked as an operations research analyst in the Pentagon, director of research for the Maryland Hospital Association, and a computer consultant for government, business, and industry. He retired from Loyola after a 24-year career teaching undergraduate, graduate, and executive MBA 
sections in computer science, telecommunications, programming, strategic use of information systems, and cyber security. E-mail: geo@loyola.edu

\section{REFERENCES}

1. AACSB. (2007). AACSB assurance of learning standards: An interpretation. http://www.aacsb.edu/accreditation/papers/AOLPaper-final-11-20-07.pdf.

2. Armstrong, M. B. (1993). Ethics and professionalism in accounting education: A sample course. Journal of Accounting Education, 11 (Spring), 77-92. doi:10.1016/0748-5751(93)90019-F

3. Awasthi, V. N., \& Staehelin, E. (1995). Ethics and Management Accounting: Teaching note for a video case, “The Order: A Progressive Disclosure Vignette." Journal of Accounting Education, 13(1), 87-98. doi:10.1016/0748-5751(94)00023-9

4. Canning-Wilson, C. (2000, November). Practical aspects of using video in the foreign language classroom. Internet TESL Journal, 6(11), 1. http://iteslj.org/Articles/Canning-Video.htm.

5. Castleberry, G. T., \& Evers, R. B. (2010, January). Incorporate technology into the modern language classroom. Intervention in School and Clinic, 45(3), 201-205. doi: 10.1177/1053451209349535

6. Committee of Sponsoring Organizations (COSO) (1992). Internal Control-Integrated Framework. New York, NY: AICPA. Available at: http://www.coso.org.

7. Davis, M. (1998). Ethics and the University. London, UK: Routledge.

8. Delaney, J., \& Coe, M. J. (2008). Does ethics instruction make a difference? Advances in Accounting Education, 9, 233-250. Bingley UK: Emerald Publishing Group, Ltd. doi: 10.1016/S1085-4622(08)09011-1

9. Fink, L. D. (2003). Creating Significant Learning Experiences: An Integrated Approach to Designing College Courses. San Francisco, CA: Jossey-Bass.

10. Freeman, R. E. (2009, May). http://www.youtube.com/watch?v=ghokREsbaoI.

11. Hanson, K. O. (2010, February). Business ethics in action: Jesuit business school strategies for emerging business executives. http://www.scu.edu/ethics/practicing/focusareas/business/jesuit.html.

12. Haywood, M. E., McMullen, D. A., \& Wygal, D. E. (2004). Using games to enhance student understanding of professional and ethical responsibilities. Issues in Accounting Education, 19 (1), 85-99.

13. Institute of Management Accountants. (2010, February). http://www.imanet.org/ ethic series1.asp.

14. Langenderfer, H. Q., \& Rockness, J. W. (1989). Integrating ethics into the accounting curriculum: Issues, problems and solution. Issues in Accounting Education. 4 (Spring), 58-69.

15. Levy, D., \& Mitschow, M. (2008). Accounting ethics education: Where do we go from here? Research on Professional Responsibility and Ethics in Accounting, 13, 135-154. doi: 10.1016/S1574-0765(08)13007-2

16. Loeb, S. E. (1978). Ethics in the Accounting Profession. Hamilton Series in Accounting and Information Systems. Santa Barbara, CA: John Wiley \& Sons.

17. (1988). Issues relating to teaching accounting ethics: An 18 year retrospective. Research on Professional Responsibility and Ethics in Accounting, 11, 1-30. doi: 10.1016/S1574-0765(06)11001-8

18. Mintz, S. M. (1990). Ethics in the management accounting curriculum. Management Accounting (June), $51-54$.

19. (1995). Ethical obligations of management accountants. Management Accounting (March), 42-45

20. Savage, A., Normand, C. S., \& Lancaster, K. A. S. (2008). Using a movie to study the COSO internal control framework: An instructional case. Journal of Information Systems, 22(1), 63-76.

21. Shaftel, J., \& Shaftel, T. L. (May 2007). Educational Assessment and the AACSB. Issues in Accounting Education, 22 (2), 215-232

22. Zhao, Y. (2003). Recent developments in technology and language learning: A literature review and metaanalysis. CALICO Journal, 21(1), 7-27. 


\section{APPENDIX 1}

\section{Purpose and the Instructions for the IMA Video Project}

Objective 5.2 of the Department of Accounting states that accounting students should be able to "Demonstrate the ability to identify ethical issues in cost accounting and apply the IMA code of ethics (principles and rules) to make ethical business decisions."

In order to carry out this responsibility I have reserved lab time on Thursday, October 22, 29, and November 5, for learning about the IMA code of ethics. During this period we will watch and discuss an IMA video called Success without Compromise. You are expected to participate in the discussion and share your perspective with me and your classmates. A team of advisory board members will assess your understanding of the issue and help you to see it from their perspective.

The learning objectives of this practice are to help you to:

1. Understand the principles and standards of IMA's Statement of Ethical Professional Practice;

2. Evaluate the possible outcomes and implications of ethical and unethical behavior within the finance function; and

3. Apply standards of good ethical practice to real-world situations. The IMA says the following about the video.

Success without Compromise" is an introductory ethics course ... created specifically for IMA members but applies to anyone working within finance and accounting. It details the history of Ethics at IMA and the development of the Statement of Ethical Professional Practice. Each overarching principle listed on the Statement is reviewed and the importance of maintaining good ethical behavior when documenting information, communicating information, and making recommendations is emphasized. Next, the Standards of Credibility, Confidentiality, Competence and Integrity guide users through a video case study of a real-life ethical dilemma. The steps for resolving an ethical dilemma provide the details for facing ethical conflicts in order to make good decisions.

\section{Alternative Assignment}

You may choose one of the following two approaches in providing feedback to me and the evaluation team. These are very similar in content and different only in form. In both case you should particularly familiarize yourself with the "Key InfoCom Employees" listed on page 16 of the "participants guidelines" posted on Blackboard. Please review this document before we meet.

\section{Alternative I: Individual Report}

After watching the video answer the following four questions.

1. What are the ethical issues apparent here?

2. How would you deal with these ethical issues?

3. What are the consequences of your proposed courses of action?

4. What basis do you have for your proposed course of action?

In answering these questions, you may concentrate on all or only one of the characters in the video. Be sure to be specific in using the proper terminologies used in the IMA code of professional ethics.

Alternative II: Team Video

If you are interested in this alternative, you should first form a team of six or seven with your classmates. Then after you watch the video, each one of you should play one of the characters in the video and make a confession dealing with the following questions. 
1. What are the ethical issues that you personally have violated?

2. How should you have dealt with the issues?

3. What were the consequences of your action?

4. What basis do you have for your conclusion?

You might also follow the "Participant Guidelines" in Appendix 2, concentrating on resolving InfoCom's dilemma. In preparing your video you must adhere to the following rules.

1. Video has a 10-minute time limit;

2. Video file has a 1 GB size limit, compressed if necessary;

3. Video must include no copyrighted materials; and

4. Video must include no jokes or language in poor taste.

In both case you should also include the following:

1. State the principles and standards of IMA Statement of Ethical Professional Practice

2. Explain the IMA's recommended process for resolving ethical conflicts.

3. Identify the different perceptions of ethics among the supervisors and subordinates.

We will then follow the Sellinger approach in evaluating and assessing the learning outcome by:

1. Choosing a sample of responses at random

2. Removing all identifiers (name or number);

3. Filling out a prepared form to grade the sampled responses using a structured rubric (by each of the three readers/observers); and

4. Calculating the average grades and entering them into Waypoint as the final assessment/evaluations of the outcome.

The benefits of this project include the following.

1. It provides synergy between an educational institution (Loyola University Maryland) and a professional institution such as Institute of Management Accountants (IMA).

2. Using video will add entertainment value to the process and therefore will be a more interesting experience for the students.

3. A professionally developed video is cost effective for the class, since it brings a valuable resource at a minimum cost to students.

4. The video and the case presentation involve the senses of both seeing and hearing.

5. Some literature suggests that this will make for a more effective learning experience.

6. Students who choose to produce video response will learn another skill to add to their profile.

7. We can use the information we collect from students to differentiate between the effectiveness of the two alternatives-writing a paper versus producing a video. 


\title{
APPENDIX 2
}

\section{Activity for Resolving InfoCom's Dilemma}

For this activity, you will work in groups of six or seven people. Participants in each group should choose one InfoCom employee from the list below. Only one participant may take each character.

\author{
Evan Slater \\ Mike Sergio \\ Karen Patella \\ Ross London \\ Neil Kim \\ Gordon Jamison
}

You may use the following format to organize and summarize your understanding of the case:

Your character:

What facts do I face?

What are my alternatives?

What do the rules say?

Why do I feel pressured?

What are the consequences of my alternatives? 


\section{APPENDIX 3}

\section{Scoring Rubric for Direct Evaluation of Learning}

Learning Goal

Each student shall demonstrate the ability to identify ethical issues in cost accounting and apply the IMA code of ethics (principles and rules) to make ethical business decisions.

Traits
1.
2.
3.
4.

Recognizes ethical issues
Proposes solutions to ethical dilemmas
Recognizes consequences of solutions to various stakeholders
Justifies solutions chosen through ethical reasoning

$\begin{array}{lll}3 & 2 & 1 \\ \square & \square & \square \\ \square & \square & \square \\ \square & \square & \square \\ \square & \square & \square\end{array}$

Scoring:

4-6 Does not meet expectations

7-9 Meets expectations

10-12 Exceeds expectations

Scoring Guide

$\underline{\text { Recognition (1) }}$

3. Recognizes multiple ethical issues.

2. Recognizes and identifies at least one ethical issue correctly.

1. Unable to recognize ethical issues.

$\underline{\text { Solutions (2) }}$

3. Proposes three or more solutions to the dilemma that are plausible in terms of principles and standards of IMA's Statement of Ethical Professional Practice.

2. Proposes one or two solutions to the dilemma that are plausible in terms of principles and standards of IMA's Statement of Ethical Professional Practice.

1. Unable to propose any plausible solutions to the dilemma.

\section{Consequences (3)}

3. Articulates both positive and negative consequences for a wide range of stakeholders.

2. Articulates either positive or negative consequences; or considers only a limited number of stakeholders.

1. Unable to articulate either positive or negative consequences to most of the proposed solutions; fails to consider a wide range of stakeholders.

\section{$\underline{\text { Justification (4) }}$}

3. Clearly identifies ethical theory or principle and uses it to justify recommendation.

2. Identifies theory or principle and attempts to use it to justify recommendation.

1. Fails to correctly identify ethical theory or principle or uses it incorrectly to justify recommendation. 


\section{APPENDIX 4}

\section{Student Assessment of IMA Ethics Video}

Introduction and Purpose

The purpose of this exercise is to get your feedback regarding the three week program in learning about professional ethics through the IMA Video Success without Compromise. This feedback will provide me with information about the utility of this activity and assist me in making the program more effective in the future. Please provide me with any constructive comments, which may help me to reinforce or improve the coverage in the future. I have intentionally provided an open ended question to get your overall input. I would like to know what you find to be strengths or weaknesses in both design and delivery of the project. You may choose to address the relevance of the project, meaningfulness of the story, usefulness of the assignment to your learning experience, the value of using blackboard, the effectiveness of guest speakers or other items in your feedback. Please be generous in providing me with your feedback.

1. Strength (keep as is).

2. Weakness of course (Modify).

3. Overall Comment. 


\section{APPENDIX 5}

\section{Indirect Assessment-Student Responses to Appendix 4}

The followings are some representative responses. In total, there were sixty six complete responses (available upon request).

\begin{tabular}{|c|c|c|}
\hline Strength & Weakness & Overall Comment \\
\hline $\begin{array}{l}\text { I thought that showing a video was } \\
\text { helpful as opposed to just reading about } \\
\text { ethics or listening to a speaker. The } \\
\text { example put forth was simple but } \\
\text { educational. The real life examples also } \\
\text { helped a lot. }\end{array}$ & $\begin{array}{l}\text { The directions on the paper were } \\
\text { somewhat vague and confusing. }\end{array}$ & $\begin{array}{l}\text { It was pretty educational and helpful } \\
\text { overall. }\end{array}$ \\
\hline $\begin{array}{l}\text { The guest speakers provided very } \\
\text { insightful information which was } \\
\text { beneficial in reinforcing the ideals of } \\
\text { the video which proves that these } \\
\text { issues are real and can directly affect } \\
\text { each of us. I enjoyed the story and } \\
\text { working in a group to portray the } \\
\text { unethical issues. }\end{array}$ & $\begin{array}{l}\text { The first week of the video was rather } \\
\text { dry and I wish it could have stated } \\
\text { specific examples of unethical issues. }\end{array}$ & \\
\hline $\begin{array}{l}\text { I thought the video was helpful to } \\
\text { understand unethical situations in the } \\
\text { workplace. }\end{array}$ & $\begin{array}{l}\text { The directions were a little confusing, } \\
\text { but I understood the over-all idea of } \\
\text { what needed to be accomplished. }\end{array}$ & Good learning tool. \\
\hline $\begin{array}{l}\text { Great video, interesting speaker } \\
\text { presentations, very structured and well- } \\
\text { thought out meetings. }\end{array}$ & $\begin{array}{l}\text { Shorten the length of the meetings } 3 \\
\text { weeks with separation leaves room for } \\
\text { forgetting the intended models. }\end{array}$ & Good work. \\
\hline $\begin{array}{l}\text { The availability of the video through } \\
\text { blackboard. The teaching style is more } \\
\text { informative than the conventional } \\
\text { learning through textbooks. }\end{array}$ & A little too long. & $\begin{array}{l}\text { Learned more about ethics than I did } \\
\text { before watching. }\end{array}$ \\
\hline Great video and speaker presentations. & $\begin{array}{l}\text { The video was fun to watch but the } \\
\text { educational part was kind of boring. } \\
\text { Make us watch the story first and then } \\
\text { the explanation of the ethics afterwards. }\end{array}$ & Good video, make amount shorter. \\
\hline $\begin{array}{l}\text { The video is a great tool for learning } \\
\text { ethical standards. We made a video } \\
\text { response and it was very helpful } \\
\text { because it put us in the situation and } \\
\text { made the consequences of unethical } \\
\text { behavior seem much more real. }\end{array}$ & I think everyone should do a video. & Very good learning experience. \\
\hline $\begin{array}{l}\text { Story, description of events and ethical } \\
\text { dilemmas was very clear. IMA workbook } \\
\text { was helpful. Guest speakers were good. } \\
\text { Have great examples of real life fraud. }\end{array}$ & $\begin{array}{l}\text { Unnecessary to have } 3 \text { class meetings } \\
\text { to watch video. Blackboard is fine. }\end{array}$ & $\begin{array}{l}\text { Very helpful in understanding } \\
\text { ethics in accounting. }\end{array}$ \\
\hline $\begin{array}{l}\text { Good enforcement of the code of } \\
\text { ethics, gets the class involved with } \\
\text { videos, speakers were very insightful \& } \\
\text { told good stories. }\end{array}$ & $\begin{array}{l}\text { Helped to watch video numerous times. } \\
\text { Liked to watch the video on my own so } \\
\text { I could watch it more than once. }\end{array}$ & $\begin{array}{l}\text { I enjoyed this program and it helped me } \\
\text { better understand the significance and } \\
\text { true about ethics in accounting. }\end{array}$ \\
\hline $\begin{array}{l}\text { Helps develop understanding of the } \\
\text { IMA code of ethics and its standards. } \\
\text { Raises awareness that conflicts of } \\
\text { ethics arise quite often in the real } \\
\text { world. Guest speakers who have dealt } \\
\text { with experiences like this. }\end{array}$ & $\begin{array}{l}\text { Have videos be watched at home not in } \\
\text { lecture. }\end{array}$ & \\
\hline $\begin{array}{l}\text { The speakers were good b/c they told } \\
\text { us real business examples }+ \text { let us } \\
\text { know what to expect in the workplace. }\end{array}$ & $\begin{array}{l}\text { Have us watch video on our own time }+ \\
\text { limit the presentation to one day rather } \\
\text { than } 3 \text {. }\end{array}$ & \\
\hline
\end{tabular}




\begin{tabular}{|c|c|c|}
\hline $\begin{array}{l}\text { I enjoyed watching the student make } \\
\text { videos. They helped to understand the } \\
\text { ethics on a more personable level. }\end{array}$ & Give the 3 videos different topics. & \\
\hline $\begin{array}{l}\text { It was a good workshop on ethics } \\
\text { because it is really not covered in any } \\
\text { of our accounting classes. }\end{array}$ & $\begin{array}{l}\text { It was a good workshop on ethics } \\
\text { because it is really not covered in any } \\
\text { of our accounting classes. }\end{array}$ & $\begin{array}{l}\text { Good overview of modern day ethical } \\
\text { dilemmas \& how we should deal. }\end{array}$ \\
\hline $\begin{array}{l}\text { The video was actually very } \\
\text { interesting, definitely keep as is, but } \\
\text { urge for students to present video } \\
\text { more. }\end{array}$ & $\begin{array}{l}\text { Not enough time to do the video but } \\
\text { between studying and other work it was } \\
\text { tough. }\end{array}$ & Awesome! \\
\hline $\begin{array}{l}\text { The project really showed some good } \\
\text { examples of how ethics is a part of } \\
\text { business. The videos were fun and } \\
\text { entertaining. Guest speakers were very } \\
\text { informative. }\end{array}$ & $\begin{array}{l}\text { There was not enough time to make the } \\
\text { videos in the best of our ability. }\end{array}$ & $\begin{array}{l}\text { Good presentation. Do it again in the } \\
\text { future. }\end{array}$ \\
\hline $\begin{array}{l}\text { Story was easy to follow \& keep track } \\
\text { of which employee was which. } \\
\text { Narrator explained and clarified the } \\
\text { ethical points in the video. }\end{array}$ & Repetitive, first point was repetitive. & \\
\hline $\begin{array}{l}\text { I believe that this project was very } \\
\text { helpful in understanding the IMA code } \\
\text { of ethics. I now feel like I have a better } \\
\text { understanding of how to deal with the } \\
\text { issues discussed in the video. The } \\
\text { speakers were also very helpful. }\end{array}$ & $\begin{array}{l}\text { I don't think that it is necessary for us } \\
\text { to watch both parts of the video in } 2 \\
\text { sittings, since we can get it on } \\
\text { blackboard. }\end{array}$ & \\
\hline $\begin{array}{l}\text { The different alternative for assessment } \\
\text { was nice to have a choice. I enjoyed the } \\
\text { real life experiences at the end. }\end{array}$ & $\begin{array}{l}\text { I don't think that it necessarily needed } \\
\text { to span } 3 \text { weeks. Maybe having } \\
\text { someone explain the IMA code of } \\
\text { conduct instead of watching the } 1 \text { st } \\
\text { video would have been more } \\
\text { interactive. }\end{array}$ & $\begin{array}{l}\text { Liked learning about this aspect of } \\
\text { accounting. }\end{array}$ \\
\hline $\begin{array}{l}\text { Video segments were very informal, } \\
\text { story was interesting and catchy, video } \\
\text { projects were a good assessment, } \\
\text { speakers were good. }\end{array}$ & $\begin{array}{l}\text { Bring up more personal experience. } \\
\text { More time on the assessment. }\end{array}$ & Overall, strong exercise. \\
\hline $\begin{array}{l}\text { Keep the same video and keep it } \\
\text { available on Blackboard. It was good } \\
\text { to have the video split up into parts. } \\
\text { Provided a real-world situation of a } \\
\text { conflict of ethics. Guest speakers } \\
\text { provided interesting personal } \\
\text { experiences. }\end{array}$ & $\begin{array}{l}\text { Video only showed a black \& white } \\
\text { ethics discussion. Maybe show } \\
\text { additional scenes of an ethical conflict } \\
\text { that involves the "grey area" of ethics. }\end{array}$ & $\begin{array}{l}\text { Very helpful toward my under-standing } \\
\text { of ethics and the proper resolution } \\
\text { techniques. }\end{array}$ \\
\hline $\begin{array}{l}\text { I think both alternative assignments } \\
\text { were fair \& good at assessing the } \\
\text { information that was presented. The } \\
\text { stories from the guest speakers were } \\
\text { beneficial b/c they gave us their real } \\
\text { world experiences. }\end{array}$ & $\begin{array}{l}\text { I think it would have been better if we } \\
\text { didn't watch the movie in class \& } \\
\text { watched in on our own time. }\end{array}$ & \\
\hline
\end{tabular}




\section{EXHIBIT 1}

\section{IMA Statement of Ethical Professional Practice}

Members of IMA shall behave ethically. A commitment to ethical professional practice includes overarching principles that express our values and standards that guide our conduct.

\section{Principles}

IMA's overarching ethical principles include: Honesty, Fairness, Objectivity, and Responsibility. Members shall act in accordance with these principles and shall encourage others within their organizations to adhere to them.

\section{Standards}

A member's failure to comply with the following standards may result in disciplinary action.

\section{Competence}

Each member has a responsibility to:

1. Maintain an appropriate level of professional expertise by continually developing knowledge and skills.

2. Perform professional duties in accordance with relevant laws, regulations, and technical standards.

3. Provide decision support information and recommendations that are accurate, clear, concise, and timely.

4. Recognize and communicate professional limitations or other constraints that would preclude responsible judgment or successful performance of an activity.

\section{Confidentiality}

Each member has a responsibility to:

1. Keep information confidential except when disclosure is authorized or legally required.

2. Inform all relevant parties regarding appropriate use of confidential information. Monitor subordinates' activities to ensure compliance.

3. Refrain from using confidential information for unethical or illegal advantage.

Integrity

Each member has a responsibility to:

1. Mitigate actual conflicts of interest; regularly communicate with business associates to avoid apparent conflicts of interest. Advise all parties of any potential conflicts.

2. Refrain from engaging in any conduct that would prejudice carrying out duties ethically.

3. Abstain from engaging in or supporting any activity that might discredit the profession.

\section{Credibility}

Each member has a responsibility to:

1. Communicate information fairly and objectively.

2. Disclose all relevant information that could reasonably be expected to influence an intended user's understanding of the reports, analyses, or recommendations.

3. Disclose delays or deficiencies in information, timeliness, processing, or internal controls in conformance with organization policy and/or applicable law. 


\section{Resolution of Ethical Conflict}

In applying the Standards of Ethical Professional Practice, you may encounter problems identifying unethical behavior or resolving an ethical conflict. When faced with ethical issues, you should follow your organization's established policies on the resolution of such conflict. If these policies do not resolve the ethical conflict, you should consider the following courses of action:

1. Discuss the issue with your immediate supervisor except when it appears that the supervisor is involved. In that case, present the issue to the next level. If you cannot achieve a satisfactory resolution, submit the issue to the next management level. If your immediate superior is the chief executive officer or equivalent, the acceptable reviewing authority may be a group such as the audit committee, executive committee, board of directors, board of trustees, or owners. Contact with levels above the immediate superior should be initiated only with your superior's knowledge, assuming he or she is not involved. Communication of such problems to authorities or individuals not employed or engaged by the organization is not considered appropriate, unless you believe there is a clear violation of the law.

2. Clarify relevant ethical issues by initiating a confidential discussion with an IMA Ethics Counselor or other impartial advisor to obtain a better understanding of possible courses of action.

3. Consult your own attorney as to legal obligations and rights concerning the ethical conflict. 